\title{
Is There a Link between Income Inequality and Economic Growth in the Balkans? Testing the Kuznets Hypothesis
}

\author{
IVANA VELKOVSKA * \\ BORCE TRENOVSKI \\ KRISTIJAN KOZHESKI \\ Faculty of Economics \\ University "Ss. Cyril and Methodius" \\ Skopje, Republic of North Macedonia
}

\author{
Original scientific paper \\ UDK: 330.341:330.566(497) \\ doi: $10.3935 /$ rsp.v28i2.1764 \\ Received: September 2020
}

This paper makes an effort to test the Kuznets hypothesis in selected Balkan countries by applying panel data regression analysis for the period 2001-2012. We analyzed the following Balkan countries: 1) EU member states - Croatia, Slovenia, Greece and Bulgaria and 2) EU candidate states - North Macedonia, Bosnia and Herzegovina, Albania and Serbia. The results indicate the existence of the Kuznets curve that is flatter at initial stages of economic development, with income inequality declining at later stages of economic growth. In addition, the EU membership is correlated to lower income inequality, indicating better redistribution efforts in these countries compared to the EU candidate countries.

Keywords: income inequality, Kuznets curve, Gini index, panel data model.

JEL classification: D63, C23, O1

\section{INTRODUCTION}

The topic of income inequality has gained significant attention following the global financial and economic crisis with many economists asking the question whether its impact could have been less severe if there had been less income inequality within the countries before the crisis (Stiglitz, 2012, Piketty, 2014, Petreski et al., 2018). The income inequality has been rising both within and between countries as a result of structural changes in the labor market, the balance between labor and capital, globalization and technological changes - to name a few. Nowadays the countries are facing yet another challenge - the economic crisis caused by the coronavirus pandemic outbreak. The latest global estimates by the ILO indicate that 'more than four out of five people - 81 percent of the global workforce of 3.3 billion - are currently affected by full or partial workplace closures' (ILO Report, 2020, p.1). These changes are expected to raise the levels of income inequality even further and make the topic even more relevant today than it was a decade ago.

While the governments' responses to the 2008 crisis were mostly directed at bailing out the big banks, nowadays the measures are directed towards saving the jobs, preserving the SMEs and providing direct payments towards citizens in need.

\footnotetext{
* Ivana Velkovska, Faculty of Economics, Ss Cyril and Methodius University, bul. Goce Delcev 9V, 1000 Skopje, Republic of North Macedonia, ivana89velkovska@gmail.com
} 
The decline in aggregate demand is making the importance of the equitable income distribution more evident than ever. Stiglitz (2014) argues that 'those at the top of the distribution consume a smaller percentage of their income than those at the bottom causing weak aggregate demand unless the government undertakes offsetting actions'. The dynamics of the corona crisis is in line with this statement i.e., the steep decline in aggregate demand results in serious contractions in the economy, witnessing once again the impact of the income inequality on the economy (although this crisis is characterized by both supply and demand shocks).

The problem of income inequality has been increasingly important in the European Union as well. The European Union has recognized the threat from the increasing levels in income inequality in recent years, and has put this issue high on the European Commission agenda. The efforts to tackle income inequality in the EU were reflected in the Europe 2020 Strategy which aimed to draw at least 20 million people out of poverty and achieve greater social inclusion. Unfortunately, as the Europe 2020 Strategy reached its end, it did not achieve this aim, stating that "considerable progress is still needed for stimulating more investment in research and innovation and for fighting poverty and social exclusion' (European Commission, 2020). The pressure to tackle the issue of poverty and make the economic growth inclusive is even bigger having in mind the enlargement process towards the Western Balkan countries which have high levels of income inequality themselves. In addition, the socio-economic background of these countries is different from that of the Western European countries, thus representing a separate research challenge with a significant gap in scientific literature.

El Ouardighi and Somun-Kapetanovic (2009) show that in the 1989-2008 period there was a real convergence process of inequality in income among five Balkan countries (Albania, Bosnia-Herzegovina, Croatia, North Macedonia and Serbia), while there is divergence between income inequalities of Balkan and European Union countries, indicating that the 'development gap between Balkans and the European Union remains important'. The successful integration of the Western Balkan countries into the European Union is dependent on understanding the characteristics of the income inequality in these countries in order to provide high quality policies and reforms designed to tackle this problem.

Although the question of the relationship between income inequality and economic growth is one of the most basic questions in the literature on income inequality, it still remains one of the most complex ones to answer. Is income inequality an inevitable consequence of economic growth? Does economic growth cause a decline in income inequality? Are high levels of income inequality hindering economic growth? The relationship between income inequality and economic growth has been defined by the famous inverted U-shape Kuznets curve. According to Kuznets (1955), income inequality first rises and later falls as the economy becomes more developed. Understanding the dynamics between inequality and growth is crucial to understanding the problem of income inequality, but the empirical literature is still divided on this topic. Despite the fact that the Kuznets curve has been thoroughly examined, the literature in this field for the Balkan countries has been extremely scarce.

There is a large disparity in the level of income inequality in the Balkans as a geographic region despite the shared economic and political past and socio-economic background. In this article we study the relationship between income inequality and economic growth in the following Balkan countries: North Macedonia, Albania, Serbia, Bosnia and Herzegovina, Slovenia, Bulgaria, Croatia and Greece. Please 
note that the first four are EU candidate countries (with the exception of Bosnia and Herzegovina which is a potential candidate country, but further in the text they will all be referred to as "EU candidate countries"), and the last four are EU member states. Analyzing these two groups of Balkan countries side by side for the same period of time using comparable data could potentially discover patterns of the inequality-economic growth dynamic in the region. The analyzed period is from 2001-2012. For this purpose, we use panel regression using the Stata13 statistical software package and we try to find out if the relationship between the economic growth and income inequality in the selected Balkan countries follow the shape of the Kuznets curve and whether the EU membership has a positive effect on income inequality.

The article is organized as follows. The second section provides a brief review of the empirical literature on the existence of the Kuznets curve and the relationship between income inequality and economic growth in general. The third section deals with the choice of variables used in the analysis, methodological issues and some important stylized facts regarding the income inequality data for the analyzed countries. In the fourth section we discuss the econometric analysis and results. Conclusions are presented in the last section of the article.

\section{LITERATURE REVIEW}

Generally, the research on the interaction between income inequality and economic growth consulted and presented in this literature review can be grouped as follows: studies that confirm the existence of the Kuznets hypothesis; studies that partially confirm the existence of the Kuznets hypothesis; studies that reject the Kuznets hypothesis and studies that analyze the interaction between income inequality and economic growth without testing the Kuznets hypothesis.
Starting with the latter, since we have found that most studies for the Balkan countries belong to this group (although the literature is still extremely scarce), it can be stated that the available literature generally shows a significant and inverse relationship between income inequality and economic growth. A panel regression of a joint sample study analyzing the period of 2002-2011 for Western Balkan countries and the new EU member states found out that income inequality falls with rising income, while the share of the bottom quintile increases and poverty falls' (Koczan, 2016). Another study analyzing panel data for three EU candidate countries (North Macedonia, Serbia and Turkey) for the period 2005-2017 showed that 'GDP positively affects income inequality, indicating a parabolic relationship between GDP and income inequality' (Bucevska, 2019). The results of this study showed that 'an increase in income increases inequality up to some extent and reduces inequality thereafter - a finding is consistent with the Kuznets hypothesis'.

However, available literature on the relationship between income inequality and economic growth is usually related to a broader sample of countries. Such is the study of Brueckner \& Lederman (2017), with panel data for both low-income and high-income countries (according to the World Bank classification) with a long time-series since the 1960s which found that 'in low-income countries transitional growth is boosted by greater income inequality, while in high income countries inequality has a significant negative effect on transitional growth'. According to the above-mentioned study:

For the median country, a 1 percentage point increase in the Gini coefficient decreases GDP per capita growth over a 5 -year period by over 1 percentage point, while the long-run effect on the level of GDP per capita is around -5 percent. 
In addition, according to Dabla-Norris et al., (2015) who conducted panel data analyses for 59 advanced, emerging, and developing economies for the period 1980-2012:

If the income share of the top 20 percent (the rich) increases, then GDP growth declines over the medium term, suggesting that the benefits do not trickle down. In contrast, an increase in the income share of the bottom 20 percent (the poor) is associated with higher GDP growth. This is an indication that the poor and the middle class matter the most for growth via a number of interrelated economic, social, and political channels.

In 2005, Frank reported that the results from a panel cointegration technique analysis for the USA covering the period 1945-2001 also showed a negative (inverse) long-run relationship between the Gini coefficient measuring inequality and the real GDP per capita. However, according to the results, this inverse relationship was more prominent for low-income states.

Although the Kuznets curve has been widely examined for a broad sample of countries and periods, the research regarding the Balkan countries is almost non-existent. The samples are usually mixed and consist both of low-, middle- and high-income countries. A study for 80 countries during the period 1980-1985 showed that the Kuznets curve holds (Milanovic, 1994). In 2003, Banerjee and Duflo found that the growth rate is an inverted U-shaped function of net changes in inequality using non-parametric methods. A random-effect regression model analysis for the USA, covering the period from 1970 to 1990 , suggests that there is 'a continued importance of the Kuznets curve pattern of declining income inequality with economic development, even though in recent years the association has become increasingly convex to the origin, indicating increasing income inequality in the most prosperous counties' (Nielsen and Andersen, 1997).

Using cross-section analysis, Ota (2016) showed that the Kuznets inverted U-curve hypothesis is valid (with some limitations) for the Asian countries covering the period 1990-2010. Another study finds that the Kuznets curve holds under certain conditions for 26 ex-socialist countries from Eastern Europe for the 1989-2011 period (Jovanovic, 2015). The conclusion of this study suggests that inequality (before government redistribution) declines with economic growth when labour markets are more regulated, anti-monopoly policy is more effective and taxes are higher. Melikhova \& Č́ižek (2014) found that that the existence of the Kuznets curve is preconditioned by other factors and is also present in a study with one of the largest samples - 145 countries for the period 1979-2009 - stating that the inverted U-curve was found in countries with low amount of social contribution. According to Matyas et al. (1997), working with panel models for two unbalanced panel data sets of 47 and 62 countries finds:

No hard empirical evidence to support the usual econometric model formulations and the U-curve hypothesis' stating that income inequalities are more likely to be explained by complex country specific factors, and they essentially do not depend on the level of development.

Focusing on 11 developing countries for the period 1990-2015, Mongi and Kais (2018) found that the estimates of the inequality equation show divergent results. Namely, in this study the Kuznets hypothesis is accepted for two countries from the sample only.

However, equally large number of studies shows evidence against the Kuznets hypothesis (although to the best of our knowledge the literature is extremely limited for 
the Balkan countries again). Theyson and Heller (2015) examine a large sample of 147 countries for the 1992-2007 period and find that the use of different measures of development significantly affects the shape of the Kuznets curve. They use the Human Development Index as a proxy for income inequality and the results imply an S-curve instead of an inverted U-curve, meaning that at the beginning of a country's development, income inequality is falling, followed by a brief rise and then another fall in income inequality. On the other hand, Kiatrungwilaikun \& Suriya (2015) examine the Kuznets hypothesis for 91 countries for the period 2000-2012 and find a U-shaped curve between Gini coefficient and GDP per capita rather than an inverted U-curve. Ocski et al. (2015) also found a U-shape curve using panel data for EU27, EU15 and EU12 countries for the period 2004-2013. Using a panel data for USA, UK, France, and Germany for the period 1915-2014, Sayed \& Peng (2020) find a long-term curve in N-shape. Using an alternative method of testing the Kuznets curve, Huang et al. (2020) find no evidence of a Kuznets curve for the USA analyzing a time series from 1917 to 2007, and neither does Panizza, (2002), who is using a cross-state panel data for the USA from 1940-1980. Galup (2012) also found some evidence for anti-Kuznets curve when the income inequality declines in low-income countries and increases in high income countries.

\section{METHODOLOGY AND DATA}

The graphical representation of the Kuznets curve is an inverted U-shape curve that explains the relationship between income inequality and economic growth. The parabolic relationship between income inequality and economic growth means that as countries achieve greater economic development, they experience greater relative income inequality before they get back to greater relative income equality.
According to Huang et al. (2012), 'the conventional way to allow the linkage to have a $U$ shape is to incorporate a quadratic or an inverse term in an otherwise standard linear model'. In addition, Banerjee \& Duflo (2003) claim that the standard procedure to estimate the relationship between income inequality and economic growth is to assume a simple linear relationship between inequality and growth, although there are some studies that use alternative models for testing the Kuznets curve (Lind and Mehlum, 2010). Most of the literature consulted for the purpose of this paper uses panel data sets relative to cross-section or time-series analysis. Due to the absence of relevant literature studying the Kuznets curve in the Balkans, we believe that there is a need for this type of analysis in order to better understand the dynamics between income inequality and economic growth in these countries.

We are analyzing the following countries: North Macedonia, Albania, Serbia, Bosnia and Herzegovina, Croatia, Slovenia, Bulgaria and Greece. Please note that the first four are EU candidate or potential candidate countries (Bosnia and Herzegovina) and the last four are EU member states forming two groups of countries which are analyzed in one panel regression. Countries Kosovo and Montenegro are left out of the sample because of unavailable data for the Gini index for the period in question. In order to build a comparable and balanced panel data sample we study the period from 2001 to 2012 because the data are available only for these years for the selected sample countries. Other common variables for measuring inequality such as the $80 / 20$ ratio and the income of the bottom $20 \%$ of the income distribution were also unavailable.

Most of the studies testing the Kuznets curve that use the conventional method of testing estimate a panel regression in which the Gini coefficient (or the Gini index) is the dependent variable and the GDP per capita 
in its linear and quadratic form is the independent variable.

The Gini index theoretically ranges from zero, when everyone has exactly the same income, to 100 (or one) when a single individual receives all the income of a society (Milanovic, 2011). The Gini coefficient takes values from zero to one. Rarely do some studies use other variables for the income inequality than the Gini coefficient/ index. Such is the study of Huang et al. (2012) who use the variables 'income shares of the top $10 \%, 5 \%$ and $1 \%$ ' as proxies for income inequality, or the study of Theyson \& Heller (2015) who use the Human Development Index. The Theil measure (how much individual country contributes to the global inequality) is also rarely used (Filauro, 2018).
As it can be noticed from the descriptive analyses of our data, the countries of the sample are diverse in terms of their income inequality levels. For 2012, the countries among the sample had the following values of the Gini index starting from the highest to the lowest value: Bosnia and Herzegovina with a value of 39.2; Albania with 38.2; Serbia and North Macedonia with 34.3; Bulgaria and Greece with 33.8; Croatia with 28.4 and the Slovenia with a value of 25.5 - a country with the lowest Gini index in the sample, but also one of the most equal countries in the world when it comes to distribution of income. It is clear that the countries from the sample that are EU member states tend to have lower levels of income inequality compared to the EU candidate countries. It should be noted that all countries except

Figure 1

Gini coefficient for the selected countries for 2001-2012 (values 0-100).

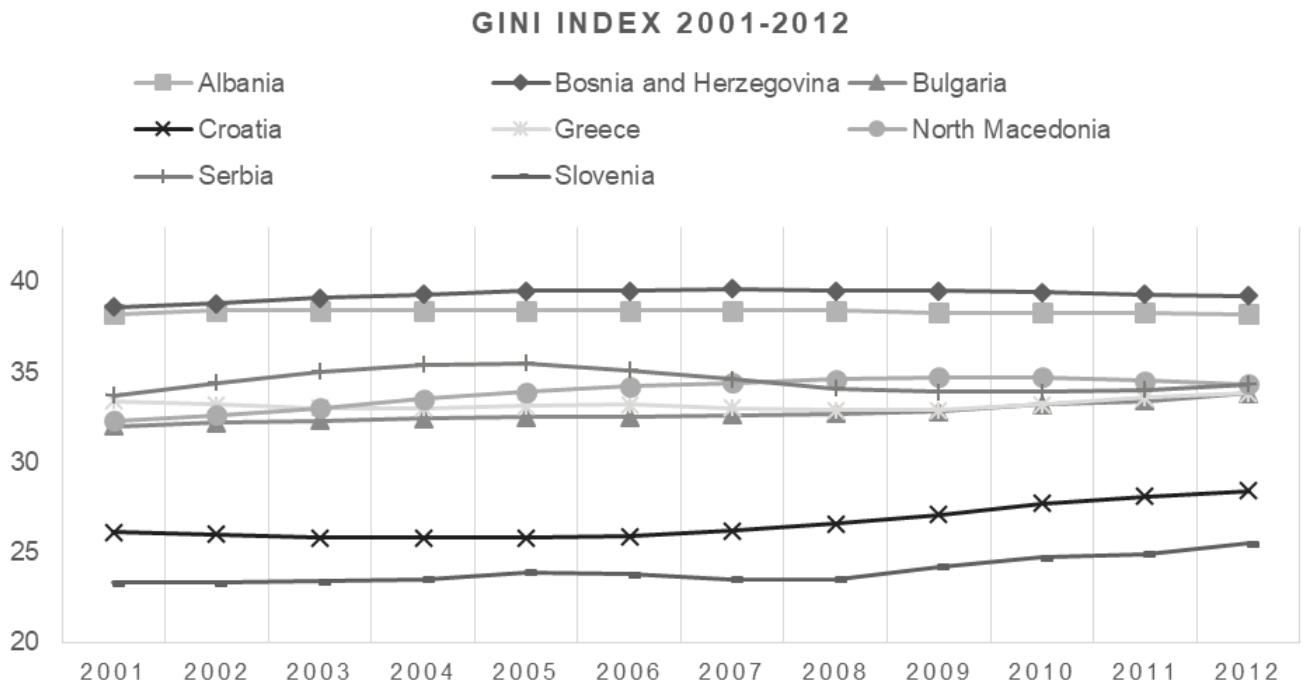

Source: World Bank online data base, retrieved April 1st, 2020, from: https://data.worldbank.org/indicator/ SI.POV.GINI 
Albania show an increase in the Gini index for the analyzed period. The highest increase in the Gini index can be noticed for Croatia and Slovenia (2.3 and 2.2 increase since 2001 respectively). North Macedonia shows an increase of 2 for the analyzed period, Bulgaria increased for 1.6, while Bosnia and Herzegovina, Albania, Serbia and Greece increased from 0.4-0.6 since 2012 (Figure 1).

Instead of GDP per capita as the independent variable, some studies use other variables - such is the study of Le et al. (2020) who use a sample of 90 countries for the period 2002-2014 and find that the Kuznets curve holds for the variables of the Gini index and export diversification as the independent variable. Nielsen \& Alderson (2007) use the medium household income, while Kiatrungwilaikun \& Suriya use the GNI per capita. In this paper we use the Gini index as a dependent variable and GDP per capita in its linear and quadratic form as the independent variable. The data we use in this paper are available at the World Bank online database.

Another reason to ask the question of the difference in the growth-inequality dynamic in the Balkans is the fact that the EU member and EU candidate countries have different and characteristic patterns in the scatter diagram of the data of the two groups.

As it can be seen from Figure 2, the scatter diagram for the data for the EU candidate countries in our sample shows a pattern that strongly resembles the inverted U-shape Kuznets curve.

On the other hand, as it can be seen on Figure 3, the scatter diagram for the data for the EU member countries in our sample shows a pattern with a steady level of income inequality at lower and medium values of GDP per capita rising sharply as the GDP per capita rises to higher values.

Figure 2

Relation of the Gini coefficient and GDP per capita (USD) for the EU candidate countries from the sample for 2001-2012
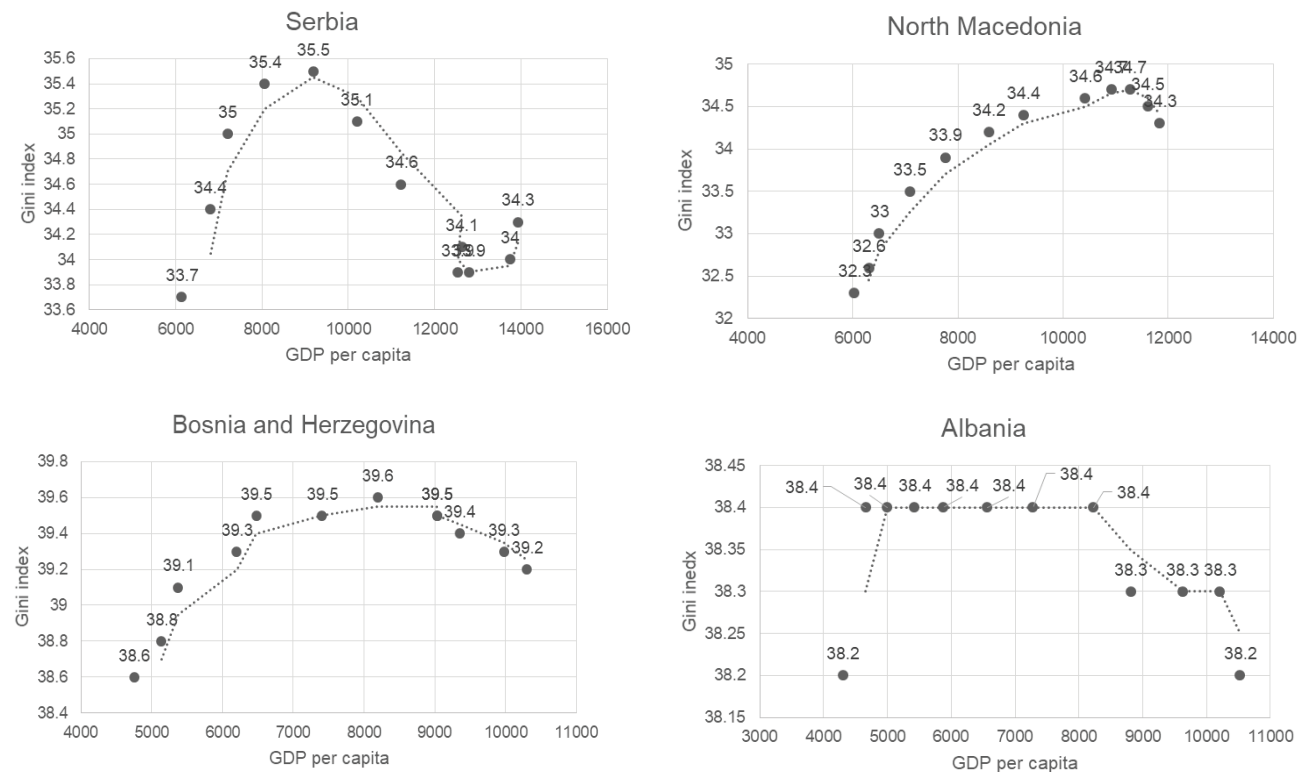

Source: World Bank online data base, retrieved April 1st, 2020, from: https://data.worldbank.org/indicator/ SI.POV.GINI and https://data.worldbank.org/indicator/NY.GDP.PCAP.CD 
Figure 3

Relation of the Gini coefficient and GDP per capita (USD) for the EU member countries from the sample for 2001-2012
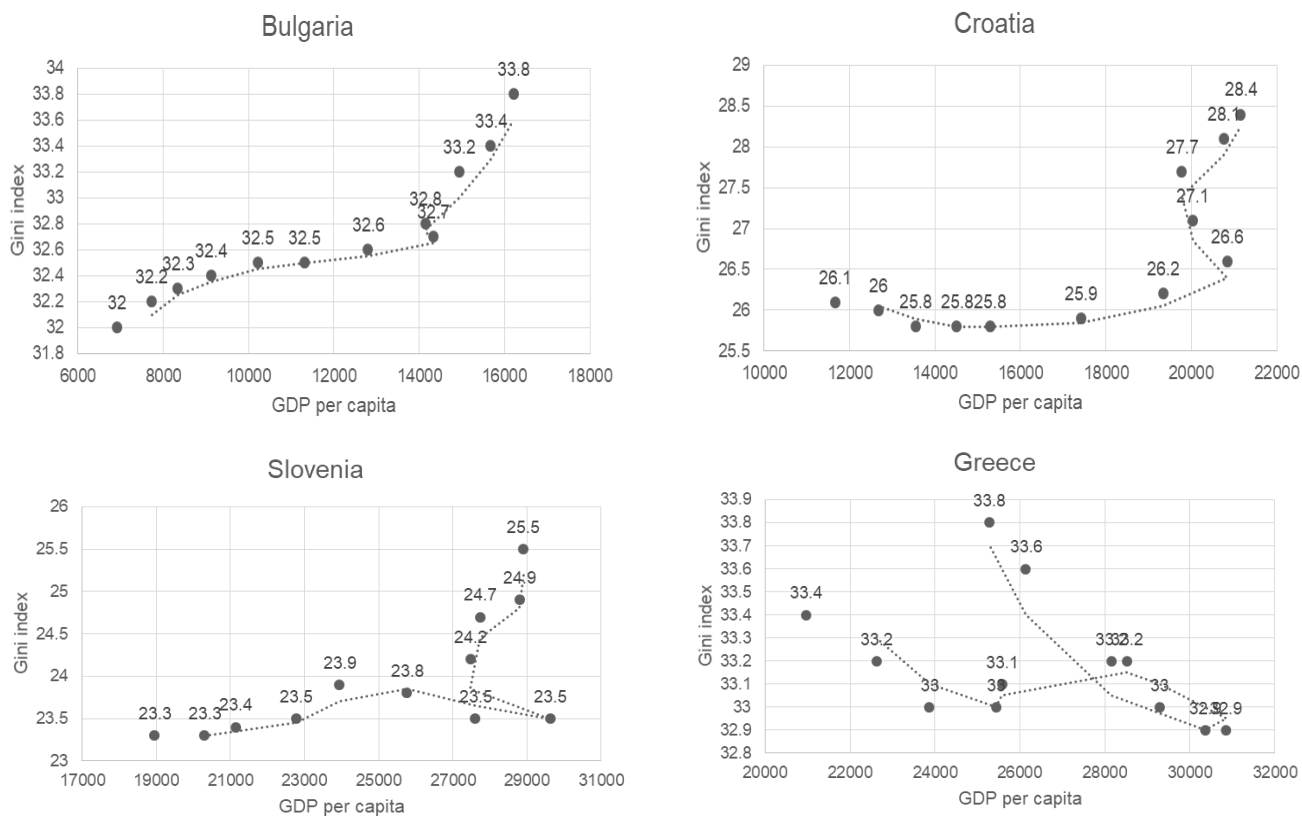

Source: World Bank online data base, retrieved April 1st, 2020, from: https://data.worldbank.org/indicator/ SI.POV.GINI and https://data.worldbank.org/indicator/NY.GDP.PCAP.CD

\section{EMPIRICAL ANALYSIS AND DISCUSSION OF RESULTS}

In what follows we provide the econometric analysis of the panel data and the discussion of the main findings. In order to test the Kuznets hypothesis, we model the Kuznets curve as a simple regression in which the income inequality is a function of the linear and quadratic form of the economic growth. For this purpose, we estimate the following equation:

$$
\begin{gathered}
\operatorname{Gini}_{i, t}=\alpha+\beta_{1} G D P_{i, t}+\beta_{2} G D P_{\mathrm{i}, \mathrm{t}-1}^{2}+ \\
+E U M+\varepsilon
\end{gathered}
$$

where $i=8$ is the number of countries in the sample, $\mathrm{t}=12$ is the number of years in the time series, $\boldsymbol{G i n i}_{\boldsymbol{i}, t}$ is the Gini index for the countries and the years covered in our sam- ple, $\boldsymbol{G D P}$ i, is the GDP per capita expressed in USD, $\boldsymbol{G D P}_{i, t}^{i}$ is the quadratic form of the GDP per capita expressed in USD, both for the countries and the years covered in our sample. The variable $\boldsymbol{E} \boldsymbol{U} \boldsymbol{M}$ is a dummy for European Union membership, taking the value of 1 for EU member states and the value of 0 for EU candidate countries. The number of observations is $\mathrm{N}=88$.

In order to test for stationarity in our variables we used the Levin, Lin \& Chu test (Table 1). The results showed non-stationarity at level only in the quadratic form of the GDP per capita, but it becomes stationary at first level. Accordingly, for this variable we used the first-difference variables as noted in the equation above. The variables Gini index and the GDP per capita proved to be stationary with consistent arithmetic mean and variance throughout the analyzed period. 
Table 1

Unit root stationarity test.

\begin{tabular}{lcc}
\hline Levin, Lin \& Chu test & \multicolumn{2}{c}{ P-value } \\
\hline Variable & At level & $\begin{array}{c}\text { 1st } \\
\text { difference }\end{array}$ \\
\hline Gini index & 0.0000 & $/$ \\
\hline $\begin{array}{l}\text { GDP per capita } \\
\text { (linear form) }\end{array}$ & 0.0103 & $/$ \\
\hline $\begin{array}{l}\text { GDP per capita } \\
\text { (quadratic form) }\end{array}$ & 0.2388 & 0.0004 \\
\hline
\end{tabular}

Source: Own calculation, Stata13 software package.

In addition, we tested the residuals for heteroscedasticity and the Pesaran test showed that the residuals are homoscedastic. Furthermore, the Breusch and Pagan Lagrangian multiplier test for random effects showed that the random effect model is appropriate. The crucial distinction between fixed effect and random effect is whether the unobserved individual effect embodies elements that are correlated with the regressors in the model, not whether these effects are stochastic or not.

Table 2

Results from the panel regression

\begin{tabular}{lcc}
\hline Variable & Coefficient & $\mathrm{p}$-value \\
\hline $\begin{array}{l}\text { GDP per capita } \\
\text { (linear form) }\end{array}$ & 0.000089 & 0.000 \\
\hline $\begin{array}{l}\text { GDP per capita } \\
\text { (quadratic form) }\end{array}$ & -2.970000 & 0.055 \\
\hline EUM & -8.417971 & 0.000 \\
\hline Intercept coefficient & 35.81761 & 0.000 \\
\hline $\begin{array}{l}\text { Coefficient of } \\
\text { determination (R2) }\end{array}$ & 0.5339 \\
\hline Source: Own calculation, Eview8 software package.
\end{tabular}

Thus specified, the results of the panel regression suggest an existence of the Kuznets curve for the Balkan states in the sample. The coefficient of determination of the regression is $53.39 \%$, meaning that this percentage of the changes in the Gini index for this sample can be explained by the changes in the GDP per capita. The slope coefficient of the variable GDP per capita in its linear form has a positive sign and is statistically significant. On the other hand, the slope coefficient for the variable GDP per capita in its quadratic form has a negative sign and it is statistically significant (Table 2). The coefficients indicate a convex function. The dummy variable EUM is also statistically significant and the coefficient has a negative sign, suggesting that the EU member states on average have lower income inequality than the EU candidate countries in the sample.

\section{CONCLUSIONS}

In this article we study the existence of the Kuznets curve in selected Balkan countries for the period 2001-2012, based on a panel regression. The countries included in the sample are the following: Croatia, Slovenia, Greece, Bulgaria, North Macedonia, Bosnia and Herzegovina, Albania and Serbia. These Balkan countries have a disparity in the level of income inequality despite the shared economic and political past. With this analysis we aimed at identifying a specific pattern in the relationship between the economic growth and the income inequality in the Balkan countries for the same period of time, using comparable data and we tried to evaluate the influence (if any) the EU membership has on income inequality. The main findings of our analysis are as follows.

Analyzing the Gini index data for the selected countries, it is noticeable that the EU member states in the Balkans have lower levels of income inequality compared to the EU candidate countries. In addition, the scatter diagrams for the data showed that the relationship between the economic growth and the income inequality in the two separate samples follows specific and characteristic patterns that resemble the Kuznets curve in the EU candidate countries.

The results of the panel regression suggest an existence of the Kuznets curve in the selected Balkan countries. However, although the coefficient of determination of the regression of $53.39 \%$ was sufficiently high not to reject the model, it indicated that the economic growth is not the only determi- 
nant of the level of income inequality in the Balkan countries of the sample. We believe that other factors may be related to effective government spending, social policy, education policy etc. Such explanatory variables have been used in the literature (Milanovic, 1994; Jovanovic, 2015; Bucevska, 2019) in models explaining the changes in income inequality, but their effects on income inequality are beyond the scope of this paper.

Regarding the EU membership, not only did the raw data of the Gini index show us that it is correlated to lower income inequality, but this has been clearly supported by the results from the panel regression analysis. Thus, the lower income inequality in the EU member states may be an indication of stronger redistributive forces compared to the EU candidate countries in the sample. Furthermore, the shape of the convex curve appears to be flatter in the beginning, i.e. in the early stages of economic development, but it falls steeper at the later stages of development. The stronger inverse effect is somewhat expected, taking into consideration that the redistributive policies are more prominent in developed countries compared to the poorer countries. The literature on income inequality suggests that as the income distribution becomes more unequal, the citizens put stronger pressure on governments to practice redistributive policies (Alesina and Rodrik, 1994). Such redistributive policies could not mean only higher taxes, but more importantly effective government spending, effective social policy, education policy and competition policy that contribute to corrections of the income inequalities in the market. This conclusion is in line with the Kuznets' theoretical expectations that income inequality decreases at the later stages of economic development as a result of income redistribution. Investigating the determinants of lower income inequality in the EU member states from the Balkans compared to the EU candidate countries from the Balkans should be subject of further research.

\section{REFERENCES}

Alesina, A., \& Rodrik, D. (1994). Distributive politics and economic growth. The Quarterly Journal of Economics, 109(2), 465-490. https://doi. org/10.2307/2118470

Banerjee, A.V., \& Duflo, E. (2003). Inequality and growth: What can the data say?. Journal of Economic Growth, 8, 267-299. https://doi. org/10.1023/A:1026205114860

Brueckner, M., \& Lederman, D. (2017). Inequality and GDP per capita: The Role of Initial Income. World Bank, University of Malaya Joint Seminar. September 14, 2017. Kuala Lumpur.

Bucevska, V. (2020). Determinants of income inequality in EU candidate countries: A panel analysis. Economic Themes, 57(4), 397-413. https:// doi.org/10.2478/ethemes-2019-0023

Dabla-Norris, E., Kochhar, K., Suphaphiphat, N., Ricka, F., \& Tsounta, E. (2015). Causes and consequences of income inequality: A global perspective. IMF Staff Discussion Note IMF SDN/15/13. Available at https://www.imf.org/external/pubs/ $\mathrm{ft} / \mathrm{sdn} / 2015 / \mathrm{sdn} 1513$.pdf

El Ouardighi, J., \& Somun-Kapetanovic, R. (2009). Convergence and inequality of income: The case of Western Balkan countries. The European Journal of Comparative Economics, 6(2), 207225. Available at https://ideas.repec.org/a/liu/ liucej/v6y2009i2p207-225.html

Eurostat. (2020). Europe 2020 indicators. Available at https://ec.europa.eu/eurostat/web/europe-2020-indicators

Filauro, S. (2018). The EU-wide income distribution: Inequality levels and decompositions. Brussels: European Commision, Directorate-General for Employment, Social Affairs and Inclusion.

Frank, Mark W. (2005). Income inequality and economic growth in the U.S.: A panel cointegration approach. SHSU Economics \& Intl. Business Working Paper No. SHSU_ECO_WP0503. Available at https://core.ac.uk/download/ pdf/6375856.pdf

Gallup, J. L. (2012). Is there a Kuznets Curve? Portland State University.

Gujarati, D. N. (2003). Basic econometrics (4th Ed.). New York: McGraw-HiII/lrwin.

Huang, H., Yeh, C., \& Lin, Y. (2012). An appropriate test of the Kuznets hypothesis. Applied Economics Letters, 19(1), 47-51. https://doi.org/10.1080/1 3504851.2011.566172

International Labour Organization. (2020). ILO Monitor: COVID-19 and the world of work. Second edition. Updated estimates and analysis. 
Available at https://www.ilo.org/wcmsp5/groups/ public/---dgreports/---dcomm/documents/briefingnote/wcms_740877.pdf

Jalil, M. M. (2016). Re-examining Kuznets hypothesis: Does data matter?. MPRA Paper No. 72557. Available at https://mpra.ub.uni-muenchen. de/72557/

Jovanovic, B. (2015). When is there a Kuznets Curve?. Department of Economics and Statistics Cognetti de Martiis. Working Papers, 50. Available at https://econpapers.repec.org/RePEc:uto:dipeco: 201550

Kiatrungwilaikun N., \& Suriya K. (2015). Rethinking inequality and growth: The Kuznets Curve after the Millennium. International Journal of Intelligent Technologies And Applied Statistics, 8(2), 159-169. https://doi.org/10.6148/IJITAS.2015.0802.08

Koczan, Z. (2016). Being poor, feeling poorer: Inequality, poverty and poverty perceptions in the Western Balkans. IMF Working Paper WP/16/31. Available at https://www.imf.org/external/pubs/ ft/wp/2016/wp1631.pdf

Kuznets, S. (1955). Economic growth and income inequality. The American Economic Review, 45(1), 1-28. https://www.jstor.org/stable/1811581

Le, T., Nguyen, C. P., Su, T. D., \& Tran-Nam, B. (2020). The Kuznets curve for export diversification and income inequality: Evidence from a global sample. Economic Analysis and Policy, 65, 21-39. https://doi.org/10.1016/j. eap.2019.11.004

Lind, J. T., \& Mehlum, H. (2010). With or without U? The appropriate test for a U-shaped relationship. Oxford Bulletin of Economics and Statistics, 72(1), 109-118. https://doi.org/10.1111/j.14680084.2009.00569.x

Melikhova, O., \& Čížek, J., (2014). Kuznets inverted U-curve hypothesis examined on up-to date observations for 145 countries. Prague Economic Papers, 23(3), 388-410. https://doi.org/10.18267/j.pep.490

Milanovic, B. (1994). Determinants of cross-country income inequality: An "augmented" Kuznets hypothesis. The World Bank Working Paper 1246. Washington, D.C. : World Bank.

Milanovic, B. (2011). More or less. Finance \& Development. Available at https:/www.imf.org/ external/pubs/ft/fandd/2011/09/pdf/milanovi.pdf

Mongi, C., \& Kais, S. (2018). Education, poverty, inequality and economic growth relationship: Fresh evidence from developing countries using a simultaneous equation model. Conference paper at 10th edition of International Finance Conference IFC10.
Nielsen F., \& Alderson, A. S. (1997). The Kuznets Curve and the great U-turn: Income inequality in U.S. counties, 1970 to 1990. American Sociological Review, 62(1), 12-33. https://doi. org/10.2307/2657450

Oczki, J., Muszyńska, J., \& Wędrowska E. (2017). Kuznets Hypothesis of income inequality: Empirical evidence from EU. Hradec Economic Days, 7(1), 643-651. http://repozytorium.umk. $\mathrm{pl} /$ handle/item/4909

Ota, T. (2017). Economic growth, income inequality and environment: Assessing the applicability of the Kuznets hypotheses to Asia. Palgrave Communications, 3, 17069. https://doi.org/10.1057/ palcomms.2017.69

Palma, J. G. (2011). Homogeneous middles vs. heterogeneous tails, and the end of the 'Inverted-U': The share of the rich is what it's all about. CWPE Cambridge Working Papers in Economics No. 1111. Available at http://www.econ.cam.ac.uk/ dae/repec/cam/pdf/cwpe1111.pdf

Panizza, U. (2002). Income inequality and economic growth: Evidence from American data. Journal of Economic Growth, 7, 25-41. https://doi. org/10.1023/A:1013414509803

Petreski, M., \& Jovanovic, B. (2018). Income inequality and the great recession: A comparative study. MPRA Paper No. 87739. Available at https:// mpra.ub.uni-muenchen.de/87739/

Picketty, T. (2014). Capital in the 21st Century. Cambridge: The Belknap Press of Harvard University Press.

Sayed A., \& Peng B. (2020). The income inequality curve in the last 100 years: What happened to the Inverted-U?. Research in Economics, 74(1), 63-72. https://doi.org/10.1016/j.rie.2019.12.001

Stiglitz, J. E. (2012). The price of inequality. New York: W. W. Norton \& Company.

Stiglitz, J. E. (2014). Reforming taxation to promote growth and equity. New York: The Roosevelt Institute. Available at https://rooseveltinstitute. org/publications/reforming-taxation-to-promote-growth-and-equity/

Theyson, K. C., \& Heller, L. R. (2015). Development and income inequality: A new specification of the Kuznets Hypothesis. The Journal of Developing Areas, 49(3), 103-118. https://doi.org/10.1353/ jda.2015.0153

World Bank. (2021b). GDP per capita (current US\$). Available at https://data.worldbank.org/indicator/ NY.GDP.PCAP.CD

World Bank. (2021a). Gini index (World Bank estimate). Available at https://data.worldbank.org/ indicator/SI.POV.GINI 


\title{
Sažetak
}

\section{POSTOJI LI VEZA IZMEĐU DOHODOVNE NEJEDNAKOSTI I GOSPODARSKOG RASTA NA BALKANU? TESTIRANJE KUZNETSOVE HIPOTEZE}

\author{
Ivana Velkovska, Borce Trenovski, Kristijan Kozheski \\ Faculty of Economics \\ University "Ss. Cyril and Methodius" Skopje, Republic \\ of North Macedonia
}

U radu se nastoji testirati Kuznetsova hipoteza u odabranim zemljama Balkana primjenom regresijske analize panel podataka za razdoblje od 2001. - 2021. godine. Analizirali smo sljedeće zemlje Balkana: 1) države članice EU - Hrvatsku, Sloveniju, Grčku i Bugarsku i 2) države kandidate - Sjevernu Makedoniju, Bosnu i Hercegovinu, Albaniju i Srbiju. Rezultati ukazuju postojanje Kuznetsove krivulje koja je izravnanija u početnim stadijima gospodarskog razvoja, a dohodovna nejednakost smanjuje se u kasnijim stadijima gospodarskog razvoja. Osim toga, članstvo u EU povezano je s nižom dohodovnom nejednakošću, što ukazuje na bolje učinke preraspodjele u tim zemljama u usporedbi sa zemljama kandidatima za članstvo u EU.

Ključne riječi: dohodovna nejednakost, Kuznetsova krivulja, Ginijev indeks, model panel podataka. 